PETERSEN, A.; STOLTZE, S. Nitrate and nitrite in vegetables on the Danish market: content and intake. Food Additives and Contaminants, v. 16, n. 7, p. 291-299, 1999.

RICHARDSON, S.J.; HARDGRAVE, M. Effect of temperature, carbon dioxide enrichment, nitrogen form and rate of nitrogen fertiliser on the yield and nitrate content of two varieties of glasshouse lettuce. Journal of the Science Food and Agriculture, v. 59, n. 3, p. 345-349, 1992.
ROORDA Van EYSINGA, J.P.N.L. Nitrate and glasshouse vegetables. Fertilizer Research, v. 5 , p. 149-156, 1984.

SANTAMARIA, P. Contributo degli ortaggi all' assunzione giornaliera di nitrato - nitrito e nitrosamina). Industrie-Alimentari, v. 36, n. 364, p. 1.329-1.334, 1997.

URRESTARAZU, M.; POSTIGO, A.; SALAS, M.; SÁNCHEZ, A.; CARRASCO, G. Nitrate accumulation reduction using chloride in the nutrient solution on lettuce growing by NFT in semiarid climate conditions. Journal of Plant Nutrition, v. 21, n. 8, p. 1.705-1.714, 1998.
WALKER, R. Nitrates, nitrites and Nnitrosocompounds - review of the occurrence in food and diet and the toxicological implications. Food Additives and Contaminants, v. 7, n. 6, p. 717-768, 1990.

WEIMIN, Z.; SHIJUN, L.; LIHONG, G; ZHONGYANG, H.; DABIAO, Z. Genetic diversity of nitrate accumulation in vegetable crops. Acta Horticulturae, n. 467, p. 119-126, 1998.

CALVETE, E.O.; KÄMPF ,A.N.; SUZIN, M. Concentração de sacarose no enraizamento in vitro de morangueiro. Horticultura Brasileira, Brasília, v. 20, n. 2, p. 186-191, junho 2.002 .

\title{
Concentração de sacarose no enraizamento in vitro de morangueiro ${ }^{1}$
}

\section{Eunice Oliveira Calvete ${ }^{2}$; Atelene Normann Kämpf ${ }^{3}$; Marilei Suzin ${ }^{2}$}

${ }^{2}$ UPF, C. Postal 611, 99.001-070 Passo Fundo-RS; ${ }^{3}$ UFRGS, Departamento de Horticultura e Silvicultura, C. Postal 776, 91.501-970, Porto Alegre-RS. E-mail:calveteu@upf.tche.br

\section{RESUMO}

O morangueiro é uma espécie de propagação vegetativa, o que explica a disseminação de doenças, quando utiliza-se plantas infestadas. Uma forma de eliminar as viroses é através da cultura de meristemas. Uma das etapas mais delicadas do processo de micropropagação é a transferência das mudas para condições ex vitro. Para garantir sucesso durante a aclimatização, faz-se necessário otimizar todas as fases do cultivo. Entre essas, encontra-se a etapa de enraizamento. Esse trabalho foi realizado nos Laboratórios da UFRGS e da UPF com o objetivo de quantificar o efeito da concentração de sacarose no meio de cultivo in vitro, na fase de enraizamento. Mudas da cultivar Campinas foram selecionadas na etapa de multiplicação e repicadas para o meio básico "MS" (Murashige \& Skoog) acrescido de $0,005 \mathrm{mg} . \mathrm{L}^{-1}$ de BAP (Benzinoaminopurina) e diferentes concentrações de sacarose $\left(0 ; 15 ; 30 ; 45\right.$ e 60 g.L. $\left.\mathrm{L}^{-1}\right)$. O delineamento experimental foi o de blocos casualizados com nove repetições. Cada parcela constou de cinco plantas por frasco, perfazendo um total de 45 unidades amostrais. Nessa etapa foram avaliadas as massas fresca e seca das folhas e raízes (mg). A partir dessas foi calculado o conteúdo de água nos tecidos. Observou-se que na ausência de sacarose não houve desenvolvimento da raiz in vitro. Plantas produzidas na concentração de 45 g. $\mathrm{L}^{-1}$ de sacarose, apresentaram maior enraizamento. Dessa forma, mudas de morangueiro Campinas apresentaram baixa capacidade fotossintética, respondendo como plantas mixotróficas ou heterotróficas.

Palavras-chave: Fragaria X ananassa Duch., biomassa, sacarose, micropropagação.

\section{ABSTRACT \\ Sucrose concentration on in vitro rooting of strawberry plants}

The vegetative propagation of strawberry plants allows dissemination of plant pathogens when infected plants are used. To avoid such pathogen transmission, especially viruses, plant merystem growing in vitro is usual. Transfer of micropropagated seedlings to ex vitro conditions, however, is a delicate process. Successful plant adaptation to ambient depends on optimum growing conditions including the rooting phase. This research was conducted at the Universidade Federal do Rio Grande do Sul and Universidade de Passo Fundo (Brazil). The effect of sucrose concentration was quantified in the culture medium over rooting of strawberry plants. Seedlings of cv. Campinas were selected during multiplication and transferred to an "MS" (Murashige \& Skoog) basic medium amended with BAP $\left(0.005 \mathrm{mg} \mathrm{L}^{-1}\right)$ and different sucrose amounts $(0 ; 15 ; 30$; 45 , and $\left.60 \mathrm{~g} \mathrm{~L}^{-1}\right)$. The experimental units were arranged according to a randomized block design with nine replicates, each replicate being a pot with five plants. The fresh and dry weight of leaves and roots were determined and used to calculate the content of water in plant tissues. While lack of sucrose resulted in no rooting, the concentration of $45 \mathrm{~g} \mathrm{~L}^{-1}$ provided the best root growth. Therefore, Campinas strawberry seedlings showed low photosynthetic capacity, behaving as mixotrophic or heterotrophic plants.
Keywords: Fragaria X ananassa Duch., biomass, sucrose, micropropagation.

\section{(Aceito para publicação em 15 de fevereiro de 2.002)}

$\mathrm{N}$ a horticultura, a técnica de cultura de tecidos tem encontrado aplicações práticas e comerciais. $\mathrm{O}$ cultivo in vitro, em especial a cultura de meristemas, pode resultar na multiplicação mais eficiente, com obtenção de materiais de melhor qualidade (Minami, 1991).
Uma das fases mais críticas na micropropagação de morangueiro, e na maioria das espécies vegetais, é a transição do meio heterotrófico para o autrotrófico (Desjardins et al., 1987). Alta taxa de sobrevivência, obtida em plantas aclimatizadas ex vitro, depende do corre- to tratamento providenciado durante o processo da transição in vitro para in vivo.

Para a formação das raízes é necessário energia. Esta pode ser oriunda da fotossíntese ou de outra fonte de açúcar. O carbono exógeno no meio de cultivo serve como fonte de energia, influ-

\footnotetext{
${ }^{1}$ Parte integrante da tese de Doutorado do primeiro autor, realizada no Departamento de Horticultura da UFRGS.
} 
enciando na fisiologia da planta, diferenciação e crescimento dos tecidos, indução e diferenciação de órgãos. A maioria das espécies forma raízes com adição de 20-30 g.L L $^{-1}$ de sacarose (George, 1996).

De acordo com a capacidade fotossintética, Grout (1988) agrupou as plantas cultivadas em meio asséptico em duas classes. Na primeira, plantas cujas folhas formadas não desenvolvem capacidade fotossintética, se crescerem em meio contendo sacarose (heterotróficas e mixotróficas). Na segunda classificação, encontram-se as plantas adaptadas para condições autotróficas in vitro que, apesar das condições artificiais de cultivo, podem apresentar uma significante taxa fotossintética.

O tipo do sistema de raízes, obtido no enraizamento in vitro, também determina o sucesso do transplante, sendo as raízes mais curtas as mais adequadas, uma vez que apresentam-se em fase de crescimento ativo, facilitando a pega da planta (Grattaplagia \& Machado, 1990).

O sucesso da aclimatização implica em alto grau de sobrevivência das plântulas e está, muitas vezes, na dependência da etapa de pré-acondicionamento in vitro. Já a fase de enraizamento é influenciada pelas modificações na constituição do meio, a fim de estimular o estabelecimento das microestacas e seu enraizamento (Debergh, 1991). Drew (1987) observou que, reduzindo a concentração mineral do meio, houve aumento na iniciação radicular de brotos de Caryca papaya. Segundo LewandoswskI (1991), 95\% de plântulas enraizadas in vitro, foram aclimatizadas com sucesso dentro de 14 dias em casa de vegetação, utilizando a combinação de ANA (0,001 mg.L. $\left.\mathrm{L}^{-1}\right)$ e AIB $(0,005$ mg. $\left.\mathrm{L}^{-1}\right)$ em meio MS com a concentração dos sais reduzidos à metade.

Aumento na porcentagem de enraizamento com o incremento da concentração de sacarose tem sido relatado para alguns protocolos de aclimatização ex vitro. Riquelme et al. (1991), na Argentina, estudaram o efeito de várias concentrações de sacarose ( 0 a 60 g.L $\left.\mathrm{L}^{-1}\right)$ na etapa de pré-acondicionamento in vitro de plântulas de morangueiro, batata, menta e videira. Resultados demonstraram que doses de 30 a 45 g.L ${ }^{-1}$ foram as mais adequadas durante o préacondicionamento in vitro e posterior sobrevivência durante a fase de aclimatização.

Da mesma forma, plântulas de Pelargonium zonale var. Rubin multiplicadas in vitro foram transferidas para meios de enraizamento com e sem sacarose. A adição de 20 g. $\mathrm{L}^{-1}$ de sacarose no meio aumentou a quantidade de plantas enraizadas, bem como o número de raízes por planta (Aldrufeu,1987).

A porcentagem de enraizamento e o comprimento das raízes de Eriostemon stardust e E. myoporoids aumentaram significativamente quando foi alterada a concentração de 25 g. $\mathrm{L}^{-1}$ para 50 g.L $\mathrm{L}^{-1}$ de sacarose, no meio de enraizamento in vitro (Ault, 1984).

Plantas de quatro cultivares de aspargo desenvolvidas em meio com alta concentração de sacarose, na fase de enraizamento in vitro, produziram raízes vigorosas e apresentaram altas taxas de crescimento e sobrevivência quando transplantadas para casa de vegetação (Conner et al., 1992). Segundo Grattaplagia \& Machado (1990), a variabilidade na resposta morfogenética in vitro, que existe não apenas entre espécies, mas também dentro de cada genótipo, leva à necessidade de se definirem protocolos diferenciados.

\section{MATERIAL E MÉTODOS}

Plantas de morangueiro da cultivar Campinas foram mantidas em casa de vegetação. No período de outubro a novembro, após a emissão dos estolões, foram coletadas as novas ramificações e desinfetadas em câmara de fluxo laminar utilizando álcool $70 \%$ por 10 segundos e hipoclorito de sódio a 50\% de cloro ativo, por 10 minutos. As gemas apicais foram retiradas em câmara de fluxo laminar, com auxílio de lupa estereomicroscópica, pinças e bisturis esterilizados.

Os explantes foram transferidos para meio de isolamento composto por meio básico de MS (Murashige \& Skoog, 1962) suplementado com 1 mg. $\mathrm{L}^{-1}$ de Benzinoaminopurina (BAP), $1 \mathrm{mg} . \mathrm{L}^{-1}$ de Ácido Indol Butírico (AIB) e $1 \mathrm{mg} . \mathrm{L}^{-1}$ de Ácido Giberélico (GA3) com $\mathrm{pH} 5,7$. Os tubos de ensaio com os explantes foram mantidos inicialmente, no escuro até o início da brotação, passando em seguida para luz e temperatura controlada, $16 \mathrm{~h}$ luz/dia entre 24 e $25^{\circ} \mathrm{C}$.

As plântulas obtidas foram transferidas para vidros com meio básico MS suplementado com $2 \mathrm{mg} . \mathrm{L}^{-1}$ de BAP e $0,5 \mathrm{mg} . \mathrm{L}^{-1}$ de $\mathrm{GA}_{3}$, constituindo-se a fase de multiplicação. As mudas oriundas da etapa anterior foram subcultivadas em frascos com meio MS acrescido de 0,005 mg.L. $\mathrm{L}^{-1}$ de BAP e $6 \mathrm{~g}$ de ágar, em diferentes concentrações de sacarose $\left(0 ; 15 ; 30 ; 45\right.$ e 60 g.L L $\left.^{-1}\right)$.

O delineamento foi de blocos casualizados com 9 repetições. Cada parcela constou de um frasco com cinco explantes, perfazendo um total de 45 unidades amostrais. Após três semanas na câmara de crescimento foi avaliada a massa fresca e seca das folhas e raízes e a partir dessas variáveis, foi calculado o conteúdo de água nos tecidos, pela diferença da massa fresca e seca e, dividido pela massa fresca, tanto para a parte aérea como para a radicular.

Os resultados foram submetidos à analise de variância. A significância das diferenças entre as médias foram avaliadas pelo teste de regressão, pelo software Sistema de Análise Estatística (SANEST). O ponto de máxima das equações quadráticas, foi obtido pela fórmula: $-b /-2 c$.

\section{RESULTADOS E DISCUSSÃO}

A variação nas dosagens de sacarose influenciou claramente a produção de biomassa, tanto na parte aérea como no sistema da raiz (Figura 1). Na sua ausência não houve formação de raiz. Dados semelhantes foram obtidos em morangueiro, batata, menta e videira por Riquelme et al. (1991), em rosa por Capellades et al. (1991) e Dorion et al. (1991) e em aspargo por Conner et al. (1992).

George (1996) relata que, para formação de raízes in vitro há necessidade de energia e carboidratos, sendo estes fornecidos através da fotossíntese (em condições autrotóficas) ou oriunda de uma fonte exógena de açúcar (em sistema heterotróficos ou mixotróficos). Como o tratamento testemunha (sem 


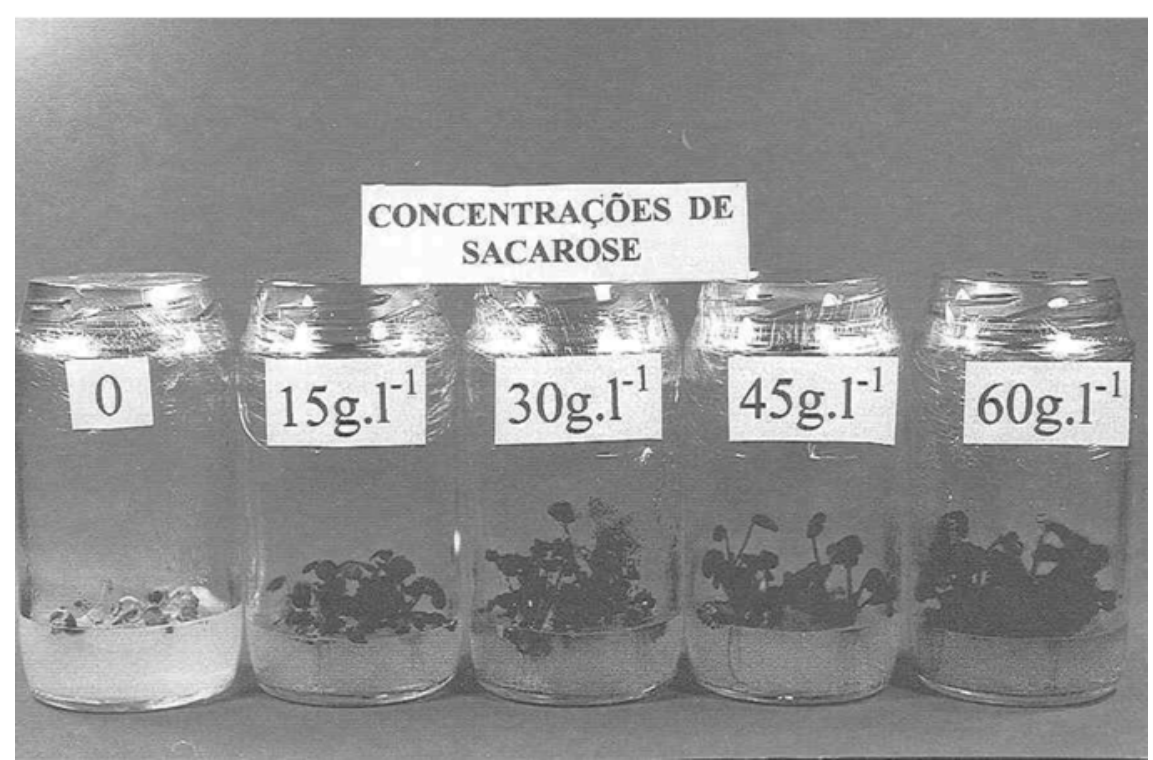

Figura 1. Mudas de morangueiro cv. Campinas em diferentes concentrações de sacarose. Porto Alegre, UFRGS, 1997.
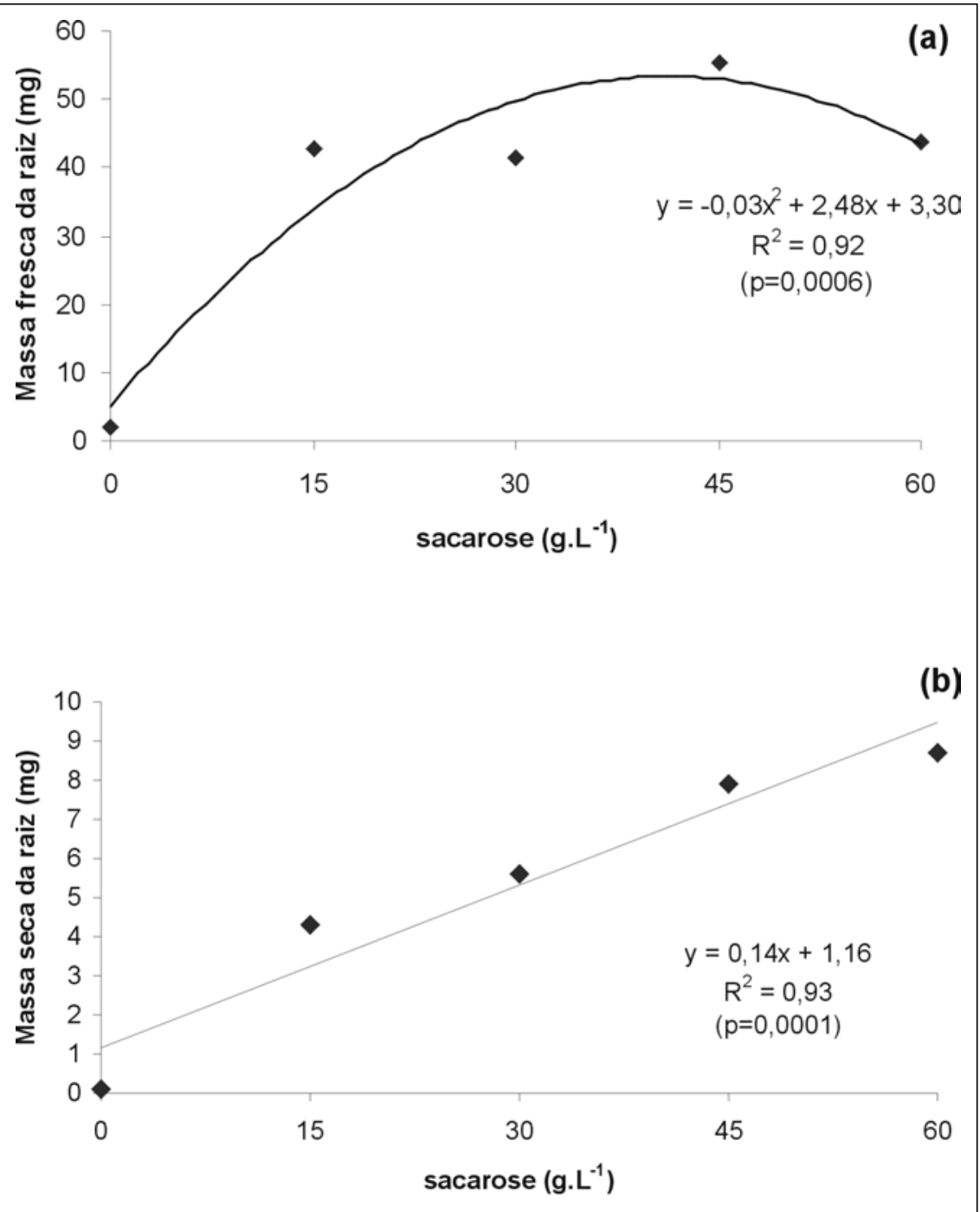

Figura 2. Efeito de diferentes níveis de sacarose na massa fresca (a) e seca (b) da raiz, durante o enraizamento in vitro. Porto Alegre, UFRGS, 1997. sacarose) não produziu raízes, os resultados encontrados sugerem que as condições encontradas no frasco de cultivo e na sala de crescimento, foram ineficientes para promover quantidades suficientes de fotossíntese.

A presença de sacarose mostrou-se fundamental para o desenvolvimento das raízes in vitro, tendo em vista que, na sua ausência não houve enraizamento. Estes resultados concordam com Mc Cown (1988), segundo o qual quando o suprimento de fotossintatos é insuficiente, não há formação de raízes in vitro.

Segundo Villegas (1990) a utilização de carbono ativado no enraizamento do morangueiro estimula a rizogênese in vitro, em relação à testemunha (ausência de carbono ativado). $\mathrm{O}$ mesmo autor ressalta, com relação à concentração, que ao aumentar a quantidade de sacarose no meio de cultivo de 0 para 2 g. $\mathrm{L}^{-1}$, aumenta-se o tamanho das raízes, no entanto o número permanece o mesmo. Adams (1972) e Boxus (1974) trabalhando com o cultivo in vitro de morangueiro, já tinham observado este comportamento.

A análise de variância dos resultados de massa fresca e seca das partes aérea e da raiz comprova o efeito quantitativo da sacarose sobre a produção da biomassa da raiz (Figura 2 e 3). O aumento da produção da biomassa da raiz foi crescente entre as dosagens usadas até 45 g.L $\mathrm{L}^{1}$, concordando com as observações de Dorion et al. (1991) e Riquelme et al. (1991). Entretanto, aumentando a dose para 60 g.L - $^{-1}$ houve redução na massa fresca, conforme pode ser observado pela aplicação da análise de regressão $\left(R^{2}=0,92\right)$ na Figura $2 a$. Esta redução sugere menor acúmulo de água na dosagem mais elevada, tendo em vista que o incremento da massa seca (Figura 2b) é linear $\left(\mathrm{R}^{2}=0,93\right)$.

Não houve diferenças na massa fresca da raiz, quando se adicionou 15 ou 30 gramas de sacarose por litro de meio de cultura. Estes dados demonstram que o comportamento do morangueiro $\mathrm{cV}$ Campinas é diferente da maioria das espécies micropropagadas que, conforme George (1996) enraízam satisfatoriamente com 20 a 30 g.L $L^{-1}$ de sacarose no meio de cultivo. 
Pela equação da curva quadrática, o ponto máximo de crescimento corresponde à dose de 41,3 g. $\mathrm{L}^{-1}$ de sacarose, o que proporcionaria o peso de $54,5 \mathrm{mg}$ de massa fresca. Os níveis de açúcar para formar raízes variam com a espécie. Lane (1978), citado por George (1996), observou que o enraizamento de maçã in vitro foi dependente da sacarose. Concentrações abaixo de 20 g. $\mathrm{L}^{-1}$ e acima de 52 g.L $\mathrm{L}^{-1}$ de sacarose reduziram a formação de raízes.

Calcula-se o aumento de 2,48 mg no peso da matéria fresca da raiz para cada grama de sacarose adicionada ao meio. Doses crescentes de sacarose promoveram acréscimos de $0,14 \mathrm{mg}$ na massa seca por grama de sacarose. $\mathrm{O}$ aumento da dosagem de 15 para 60 g. $\mathrm{L}^{-1}$ de sacarose dobrou o peso da matéria seca do sistema da raiz de 4,3 para $8,7 \mathrm{mg}$ (Figura 2b). Níveis crescentes de sacarose resultaram em aumento da biomassa in vitro, de forma semelhante tanto para a parte aérea como para a raiz. Para a adição de um grama de sacarose calcula-se o aumento de 4,4 mg de massa fresca, até o máximo de $208,7 \mathrm{mg}$, com a dose de 37,08 g de sacarose (Figura 3a). A planta, na ausência de sacarose, não acumulou energia e por isto não teve capacidade de realizar atividade metabólica. Ao incorporar 15 g. $\mathrm{L}^{-1}$ de sacarose no meio de cultivo [potencial osmótico $=-0.112 \mathrm{MPa}$ segundo George (1996)], as plântulas tiveram energia e em consequência apresentaram grande massa fresca aérea. Esta situação pode afetar a sobrevivência ex vitro, se a plântula não tiver condições energéticas apropriadas. Entretanto, aquelas plântulas de morangueiro que cresceram em meio com 45 g. $\mathrm{L}^{-1}$ de sacarose [potencial osmótico $=-0.300$ MPa segundo George (1996)], acumularam no tecido mais massa seca com menor conteúdo de água. Isto pode favorecer maior sobrevivência das plântulas ex vitro. Por outro lado, plântulas desenvolvidas em meio com $60 \mathrm{~g} . \mathrm{L}^{-1}$ de sacarose [potencial osmótico $=-0.461 \mathrm{MPa}$ segundo George (1996)], pode inibir o desenvolvimento da parte aérea (Figura 3a).

Observou-se aumento da matéria seca com o incremento da concentração de sacarose (Figura 3b). Na ausência de

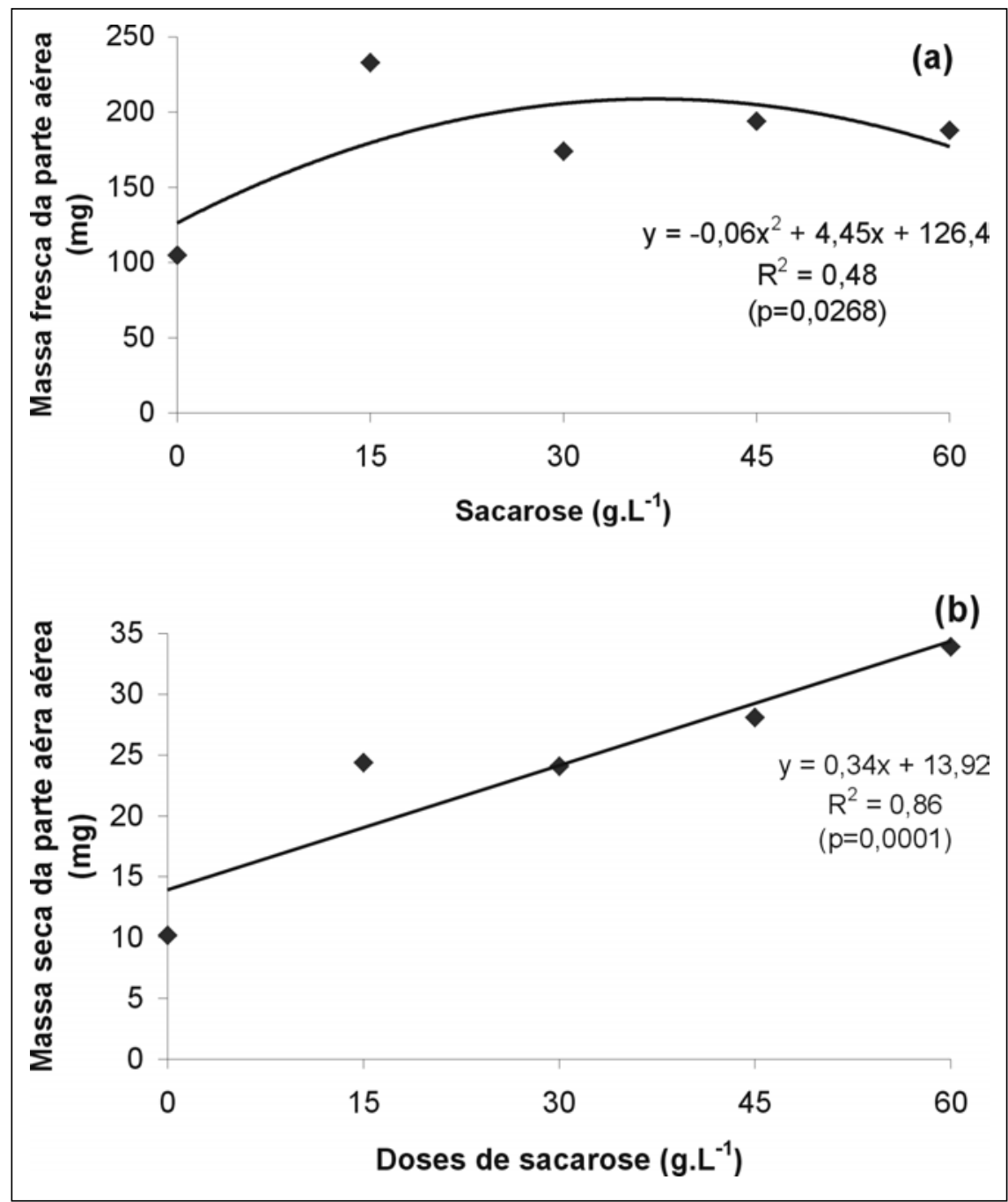

Figura 3. Efeito de diferentes níveis de sacarose na massa fresca (a) e seca (b) na parte aérea do morangueiro, na fase de enraizamento in vitro. Porto Alegre, UFRGS, 1997.

sacarose o peso da massa seca alcançado pelas mudas de morangueiro foi de $10,2 \mathrm{mg}$, enquanto a 60 g.L $\mathrm{L}^{-1}$ foi 33,9 mg. Maior conteúdo de sacarose no meio de cultivo corresponde à maior concentração de carboidratos (ou de reservas) no tecido foliar. Em conseqüência, as folhas têm capacidade de permanecer mais tempo na planta.

Para promover fotoautotrofismo nas plantas in vitro, Debergh (1991) sugere a omissão de sacarose no meio. Entretanto, os resultados aqui encontrados não confirmam esta hipótese. Langford \& Wainwright (1987) afirmam que o cultivo fotoautotrófico de células e órgãos in vitro tem sido buscado por muitos pesquisadores, mas poucos resultados foram encontrados neste sentido. Provavelmente, seria necessário modificar a intensidade de luz e concentra- ção de $\mathrm{CO}_{2}$. Esta afirmação baseia-se em trabalhos realizados com morangueiro por Arai et al. (1991), Yue et al. (1993) e Desjardins et al. (1987).

Por outro lado, um aumento na concentração de sacarose do meio de cultivo de 3 para $5 \%$ promoveu aumento de massa, em folhas de rosa micropropagadas sob condições heterotrotóficas ou mixotróficas (Capellades et al.,1991).

Constatou-se relação de dependência entre o conteúdo de água e a dosagem de sacarose no meio, com $\mathrm{R}^{2}=0,88$ para a parte aérea e $\mathrm{R}^{2}=0,95$ para as raízes (Figura 4). À medida que aumenta a concentração de sacarose diminui a porcentagem de água nos tecidos para cada grama de sacarose adicionada ao meio de enraizamento, correspondendo a um decréscimo de $3,12 \%$ de água nos 

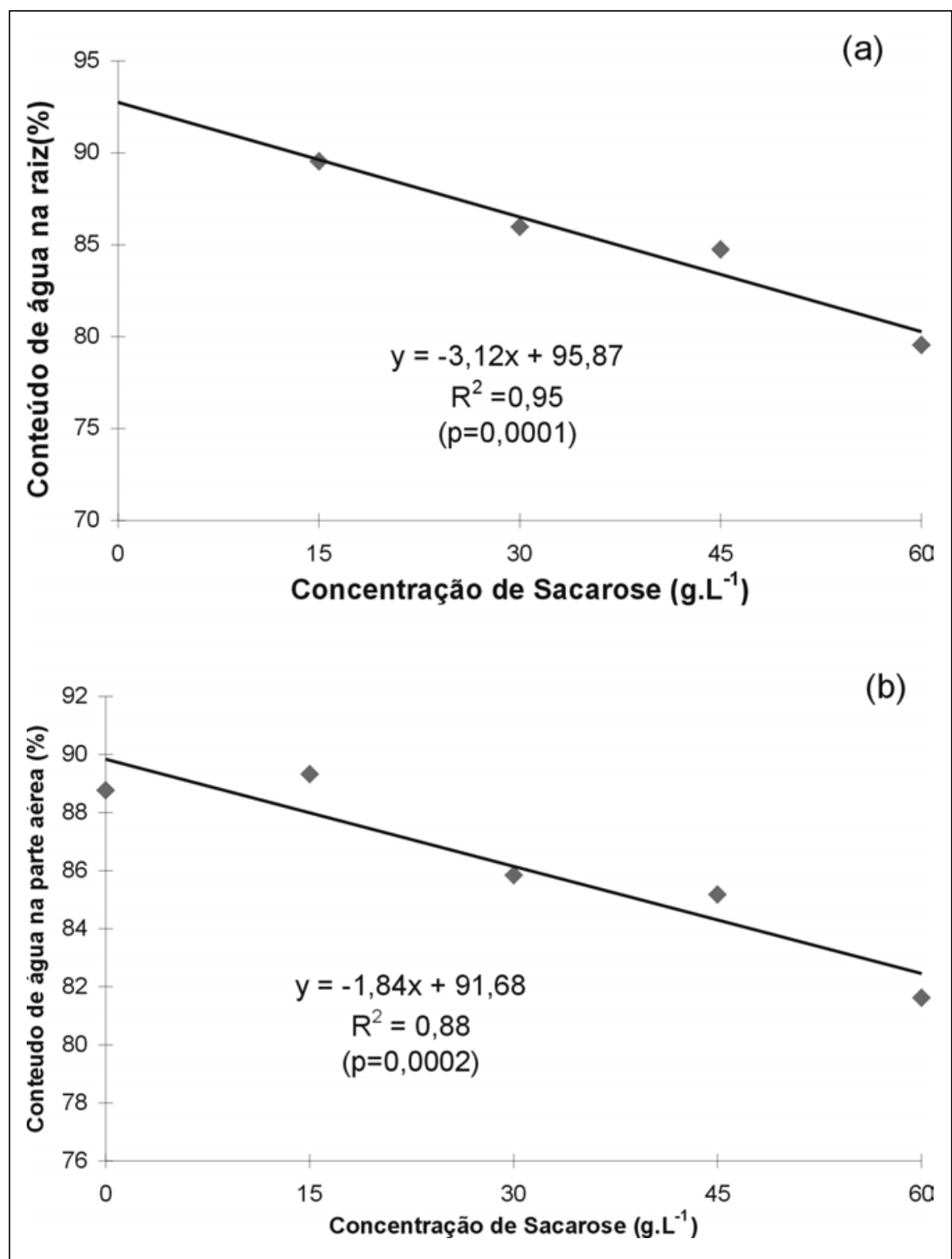

Figura 4. Conteúdo de água nos tecidos da raiz (a) e da parte aérea (b) em diferentes concentrações de sacarose, na fase de enraizamento in vitro de morangueiro cv. Campinas. Porto Alegre, UFRGS, 1997.

tecidos das raízes (Figura 4a) e de 1,84\% na parte aérea (Figura 4b).

Nas plantas oriundas das altas concentrações de sacarose ocorreu alto conteúdo de matéria seca. Conforme Salisbury \& Ross (1994), maior matéria seca de plantas in vivo significa maior acúmulo de fotossintetizados e maior absorção de minerais. Capellades et al. (1991) e Hdider \& Desjardins (1994) sugerem que, in vitro não há fotossíntese em presença de altas concentrações de sacarose, devido ao acúmulo de amido ou à inibição da enzima Rubisco. Os autores esclarecem, porém, que em plantas cultivadas in vitro sob altas concentra- ções de sacarose, a síntese reduzida dos açúcares favorece o acúmulo de carboidratos no tecido. Além disso, como já foi mencionado, pode ter ocorrido efeito osmótico no meio de cultivo in vitro.

Os resultados desse experimento evidenciaram a importância de aumentar a concentração de sacarose in vitro e, estabelece-se a dosagem de 45 g.L. L $^{-1}$ de sacarose em meio de "MS", como a melhor concentração para a produção de biomassa de mudas de morangueiro $c v$ Campinas. Entretanto, as mudas obtidas in vitro apresentaram baixa capacidade fotossintética, respondendo como plantas mixotróficas ou heterotróficas.

\section{AGRADECIMENTOS}

Ao colega Eng $^{\circ} \mathrm{Agr}^{\circ}$ Dr. Carlos Alberto Forcelini, professor da Faculdade de Agronomia e Medicina Veterinária da Universidade de Passo Fundo, pela ajuda na elaboração do abstract. Ao programa CAPES/PICDT pela concessão da bolsa de estudos, durante o curso de Doutorado.

\section{LITERATURA CITADA}

ADAMS, A.N. An improved medium for strawberry meristem culture. Journal Horticulturae Science, n. 17, p. 263-264, 1972.

ALDRUFEU, A. Rooting and acclimatization of Pelargonium zonale plantlets. Acta Horticulturae, n. 212, p. 361-366, 1987.

ARAI, S.; ASAO, H.; KOBATAKE, H. The effect of $\mathrm{CO}_{2}$ enrichment on the growth and quality of strawberry plantlets regenerated from a shoot-tip culture. Bulletim of the Nara Agricultural Experiment Station, n. 22, p. 9-16, 1991.

AULT, J.R. In vitro propagation of Eriostemon myoporpoides and Eriostemon stardust. HortScience, v. 29, n. 6, p. 686-688, 1984.

BOXUS, Ph. The production of strawberry plants by in vitro micropropagation. Journal Horticulturae Science, n. 19, p. 209-210, 1974.

CAPELLADES, M.; LEMEUR, R.; DEBERGH, P. Effects of sucrose on starch acumulation and rate of photosyntesis in Rosa cultured in vitro. Plant Cell, Tissue and Organ Culture, v. 25, n. 1, p. 21-26, 1991.

CONNER, A.J.; ABERNETHY, D.J; FALLOON, P.G. Importance of in vitro storage root development for the successfull of micropropagated asparagus plants to greenhouse conditions. HortScience, v. 20, n. 4, p. 477-481, 1992.

DEBERGH, P.C. Aclimatization techniques of plants from in vitro. Acta Horticulturae, n. 289, p. 291-300, 1991.

DESJARDINS, Y.; GROSSELIN, A.; YELLE, S. Acclimatization of ex-vitro strawberry plantlets in $\mathrm{CO}_{2}$ - enriched environments and supplementary lighting. Journal of the American Society for Horticultural Science, v. 112, n. 5, p. 846-851, 1987.

DORION, N.; KADRI, M; BIGOT, C. In vitro preservation at low temperature of rose plantlets usable for diret acclimatization. Acta Horticulturae, n. 298, p. 335-343, 1991.

DREW, R.A. The effects of medium composition and cultural conditions on in vitro root initiation and growth of papaya (Carica papaya L.). Journal of the American Society for Horticultural Science, n. 62, p. 551-556, 1987.

GEORGE, E.F. Plant Propagation by Tissue Culture. 2. Ed., Edington: Exegetics, 1996. 1361 p. Part 2: In Practice. 
GRATTAPAGLIA, D.; MACHADO; M Micropropagação In: TORRES, A.C.; CALDAS, L.S. (Eds.). Técnicas e Aplicações de Cultura de tecidos de plantas. Brasília: ABCTP: EMBRAPA CNPHortaliças, 1990. p. 99-169.

GROUT, B.W.W. Photosynthesis of regenerated plantlets in vitro, and stress of transplanting. Acta Horticulturae, n. 230, p. 129-135, 1988

HDIDER,C.; DESJARDINS, Y. Effects of sucrose on photosynthesis and phosphoenolpyruvate carboxylase activity of in vitro cultured strawberry plantlets. Plant Cell, Tissue and Organ Culture, v. 1, n. 36, p. 27-33, 1994.

LANGFORD, P.J.; WAINWRIGHT, S. Effects of sucrose concentration on the photosynthesis ability of rose shoots in vitro. Annals of Botany, v. 60, p. 633-640, 1987.
LEWANDOWSKI, V.T. Rooting and acclimatization of micropropagated Vitis labrusca "Delaware". HortScience, v. 126, n. 5, p. 586.588, 1991.

MC COWN, B.H. Adventitious rooting of tissue cultured plants. IN: DAVIS, T.; HAISSIG, B.E.; SANKLA, N. (Eds.).Adventitious root formation in cuttings. Portland-Oregon: Dioscorides, 1988. v. 2, p. 289-299.

MINAMI, K. Biotecnologia e Otimização da Produtividade dos Produtos Hortícolas. In: CROCOMO (Ed.) e colaboradores. Biotecnologia para produção vegetal. Piracicaba: ESALQ/USP: CEBTEC/FEALQ, 1991. p. 173-187.

MURASHIGE, T.; SKOOG F.A. Revised medium for rapid growth and bio assays with tobacco tissue cultures. Physiologia Plantarum, n. 15, p. 473497, 1962.
RIQUELME, C.; GUIÑAZU, M.E; TIZIO, R. Pre-acondicionamento y aclimataccion en condicciones de invernáculo de plântulas micropropagadas de frutilla, menta, papa y vid. Phyton, v. 52, n. 1, p. 73-82, 1991

SALISBURY, F.B.; ROSS, C.W. Fisiologia Vegetal. México: Iberoamérica, 1994. 759 p.

VILLEGAS, A.M. Micropropagación de fresa (Fragaria $x$ ananassa Duch.). In: ROSELL, C.H.; VILLALOBOS, V.M. (Eds.). Fundamentos teórico-práticos del cultivo de tejidos vegetales. Roma: Organizacion de las Naciones Unidas para la Agricultura e la Alimentacion (FAO), 1990. p. 91-95. YUE, D.; DESJARDINS, Y.; GOSSELIN, A. Photosynthetic capacity and effects of forced ventilation on growth of in vitro cultured strawberry plantlets. Acta Horticulturae, v. 20, p. 123-126, 1993.

MAROUELLI, W.A.; SILVA, W.L.C.; CARRIJO, O.A.; SILVA, H.R. Produção e qualidade de alho sob regimes de água no solo e doses de nitrogênio. Horticultura Brasileira, Brasília, v. 20, n. 2, p. 191-194, junho 2.002.

\title{
Produção e qualidade de alho sob regimes de água no solo e doses de nitrogênio
}

\author{
Waldir A. Marouelli; Washington L. C. Silva; Osmar A. Carrijo; Henoque R. Silva \\ Embrapa Hortaliças, C. Postal 218, 70.359-970 Brasília - DF. E-mail: waldir@cnph.embrapa.br
}

\section{RESUMO}

Avaliou-se os efeitos de regimes de água no solo e doses de nitrogênio $(\mathrm{N})$ sobre a produção e qualidade de bulbos de uma cultivar de alho suscetível ao pseudoperfilhamento. O estudo foi conduzido na Embrapa Hortaliças, Brasília, e os tratamentos consistiram da combinação de três tensões de água $(15 ; 35$ e $70 \mathrm{kPa})$ e três doses de $\mathrm{N}\left(20 ; 100\right.$ e $\left.500 \mathrm{~kg} \cdot \mathrm{ha}^{-1}\right)$. Maior desenvolvimento vegetativo, produtividade total e massa média de bulbos foram obtidos para tensões entre 15 e $19 \mathrm{kPa}$ e doses de $\mathrm{N}$ entre 52 e $97 \mathrm{~kg}$.ha ${ }^{-1}$. A produtividade comercial foi maximizada para a tensão de $15 \mathrm{kPa}$, sendo contudo reduzida linearmente com o aumento da dose de N. A porcentagem de bulbos pseudoperfilhados foi influenciada pela tensão de água, dose de $\mathrm{N}$ e pela interação dos fatores, tendo sido minimizada para a tensão de $70 \mathrm{kPa}$ e $20 \mathrm{~kg} \cdot \mathrm{ha}^{-1} \mathrm{de} \mathrm{N}$. As porcentagens de bulbos chochos e de perda de massa entre 60 e 120 dias após a colheita aumentaram linearmente com as doses de $\mathrm{N}$, mas não foram afetadas pela tensão. Assim, para maximizar a produtividade comercial de cultivares suscetíveis ao pseudoperfilhamento deve-se realizar a irrigação em regime de alta freqüência, mesmo favorecendo maior porcentagem de pseudobulbos, e minimizar a aplicação de $\mathrm{N}$.

Palavras-chave:Allium sativum, bulbo chocho, irrigação, nitrogênio, tensão de água no solo, pseudoperfilhamento.

\section{ABSTRACT}

Production and quality of garlic crop under soil water regimes and nitrogen levels

The study was carried out at Embrapa Hortaliças, Brasília, Brazil, in order to evaluate the effects of three soil water tensions $(15 ; 35$ and $70 \mathrm{kPa})$ and three nitrogen $(\mathrm{N})$ levels $\left(20 ; 100\right.$ and $\left.500 \mathrm{~kg} \cdot \mathrm{ha}^{-1}\right)$ on yield and quality of garlic bulbs of a secondary growth susceptible cultivar. Greater vegetative growth, total yield and average bulb weight were obtained under tensions between 15 and $19 \mathrm{kPa}$ and $\mathrm{N}$ levels between 52 and $97 \mathrm{~kg} \cdot \mathrm{ha}^{-1}$. The marketable yield was maximized for $15 \mathrm{kPa}$ tension, and it was linearly reduced with increasing $\mathrm{N}$ levels. The percentage of bulbs with secondary growth was affected by the water tension, $\mathrm{N}$ and the interaction of both factors, with minimum value obtained for the combination of 70 $\mathrm{kPa}$ tension and $20 \mathrm{~kg} \cdot \mathrm{ha}^{-1}$ of $\mathrm{N}$. The percentages of dry bulbs and mass loss between 60 and 120 days after harvest increased linearly with $\mathrm{N}$, however, they were not affected by water tension treatments. Hence, to maximize marketable yield of cvs. susceptible to secondary growth both high frequency irrigation regime is recommended, despite favoring secondary growth, and minimum $\mathrm{N}$ application.

Keywords: Allium sativum, dry bulb, irrigation, nitrogen, soil water tension, secondary growth.

\section{(Aceito para publicação em 31 de janeiro de 2.002)}

$\mathrm{O}$ alho é uma das hortaliças de maior relevância econômica e social no Brasil, sendo cultivada principalmente por pequenos agricultores. Nos últimos dez anos, a área média cultivada foi de 14,8 mil hectares, sendo cerca de $20 \%$ na região de cerrados 1 , principalmente nos estados de Goiás e Minas Gerais. No mesmo período, a produtividade média foi de

\section{4,8 $\mathrm{t} \mathrm{ha}^{-1}$ (IBGE, 2000).}

O alho é cultivado na estação fria, por ser muito influenciado por fotoperíodo e temperatura, o que coincide com a época mais seca do ano nas regiões Sudeste e Centro Oeste. Assim, para suprir as necessidades hídricas da cultura e garantir a obtenção de produtividade elevada e de boa qualidade, a irrigação é prática obrigatória nas principais regiões produtoras, especialmente em Minas Gerais e Goiás. Em Santa Catarina e Rio Grande do Sul é freqüente a ocorrência de estiagens durante o ciclo da cultura, e muitos agricultores já utilizam a prática da irrigação a fim de possibilitar incrementos significativos de produtividade (Pola \& Biasi, 